\title{
結合価文法による動詞と名詞の訳語選択能力の評価
}

\author{
金出地 真人 ${ }^{\dagger}$ 徳久 雅人 ${ }^{\dagger}$ \\ 村上 仁一 ${ }^{\dagger}$ 池原悟 ${ }^{\dagger}$
}

本稿は，日英機械翻訳での動詞および名詞の訳語選択における結合価文法の能力を実 験的に明らかにする．結合価文法を用いると，原言語文における用言と格要素の意味 的用法が限定されるため，正しい訳語選択ができると考えられてきた。しかし，結合 価文法は，知識ベースの開発が困難であることから，その有効性が明らかにされてい なかった．近年，14,800 個の結合価パターンが登録された大規模辞書「日本語語彙大 系」が開発された。そこで，本稿は，まず，IPAL 辞書に登録されている基本動詞およ び基本名詞に関する例文，数千文について機械翻訳を実施し，その結果を翻訳家によ る英訳と比較することで，動詞および名詞の訳語選択の正確さを検証する．次に，機 械が翻訳に誤った例文について翻訳過程を分析し，誤り原因と改善の可能性を検討す る。これらの結果，訳語選択の正解率は，基本動詞が $89 \%$ ，そして，基本名詞が $91 \%$ であった。ベースラインとして和英辞書の先頭訳語を選択する場合と比較すると，動 詞の訳語選択において結合価文法は顕著な効果が確認されたが，名詞の訳語選択につ いてはそれ程の効果は認められなかった。また，結合価文法を用いた訳語選択の方式 上の正解率の限界，すなわち，正解を導く結合価パターンが全て登録され，かつ，形態 素解析やパターン照合が完全に成功することを仮定した場合の正解率の限界は, IPAL 辞書に関連する例文において，動詞が $99 \%$ ，名詞が $97 \%$ となると推定した.

キーワード： 機械翻訳，訳語選択，文型パターン，意味属性，語義の曖昧性解消

\section{Evaluation of the English Word Selection Ability of Valency Grammar for Japanese Verbs and Nouns}

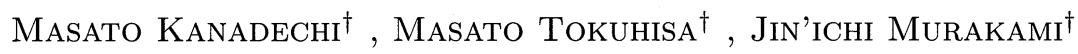 \\ and SATORU IKEHARA ${ }^{\dagger}$
}

This paper experimentally clarifies the ability of valency grammar for the word selection of verbs and nouns in machine translation. Valency grammar based translation has long been expected to confirm accurate results, because valency patterns in the grammar restrict the relationship among the meanings of a verb and nouns. However, the ability is not clarified yet because of the difficulty of developing this kind of knowledge base. Since a large scale dictionary Nihongo Goi Taikei (14,800 valency patterns) is recently realized, in this paper the examinations of translating Japanese to English are conducted for several thousands of example sentences relating to IPAL dictionaries, and the translation results of fundamental nouns and verbs are compared with human translator's translations to obtain the translation accuracy. Next, the details of translation process of wrong translations are carefully analyzed to know reason of the failures and possibility to improve them. The result shows that each accuracy for the word selection of the verbs and the nouns is $89 \%$ and $91 \%$. It is clarified that the valency grammar is effective in the selection of verbs but is not so 
effective in the selection of nouns as compared with baseline which are chosen from a Japanese/English dictionary. Further, each limitation of the accuracy for verbs and nouns by the valency grammar, which depends on the assumption of complete valency patterns, morphological analysis, and pattern matching, is estimated at $99 \%$ and $97 \%$ in the domain of the IPAL dictionaries related sentences.

KeyWords: machine translation, word selection, sentence pattern, semantic attribute, word sense disambiguation

\section{1 はじめに}

機械翻訳において訳語選択は重要な問題の一つである. 訳語選択の精度を向上させるために は，文中で使用された単語の意味（語義）を解析する必要がある.

従来研究における動詞の意味解析の方法としては, 共起レベルと頻度をパラメータとした 「尤度」および辞書的記述に基づいた「制約」を用いる方法 (野美山 1991) や, 単語の共起関係 を用いる方法 (鈴木, 太細 1991), などが提案されている. しかし, 訳語選択において高い精度 を出すに至っていない. 名詞の意味解析の方法としては, 談話解析で得られた場面情報により, 英語名詞の多義を解消する方法 (角田, 田中 1996) や, 連体修飾句の係る名詞を対象に格の情 報と意味属性を用いる方法 (北村, 荻野 1990) が提案されている。また, 名詞辞書における多 義構造の記述に関する研究 (柏野 (桑畑), 本多 1998) (桑畑, 橋本, 青山 1998) もあるが対象 は限定的である。最近では，大規模の翻訳メモリが開発されたことから用例ベースによる訳語 選択が注目されている (黒橋, 白井, 隅田, 武田, 鳥澤, 橋田 2003). 用例ベースによる方式で は，機械学習アルゴリズムとそこで用いる素性について議論がなされている。しかし，素性に は意味解析タスクの入力条件やアプリケーションに適した素性を利用しており, 意味解析で原 理的に必要となる素性の考察はなされていない.

一方, (池原, 宮崎, 横尾 1993) では, 言語過程説 (三浦 1967) の立場から, 言語表現の意味 を「表現」に結びつけられた「対象」と話者の「認識」の関係としてとらえ，日英機械翻訳の ための意味解析に用いる言語知識として「単語意味辞書」および「構文意味辞書」を構築した. 単語意味辞書は単語の持つ意味のシソーラス型の体系であり, 構文意味辞書は, 結合価文法 (水 谷, 石棉, 荻野, 賀来, 草薙 1983) に基づき意味的にまとまる単位で用言と格要素の共起関係 を記述した「文型パターン（結合価パターンとも呼ばれる）」の集合である。文型パターンによ る用言の意味分類能力を基準にした評価実験を行うことで, 単語の意味記述の粒度，すなわち， 単語辞書の「意味属性」の体系が定められている.

結合価文法を用いた意味解析では, 文中で使用される単語の意味的用法が絞り込まれること から，動詞と名詞の訳語選択に有効であると考えられる。しかし，結合価文法による訳語選択 の効果は定量的には明らかにされていない.

†鳥取大学工学部, Department of Information and Knowledge Engineering, Faculty of Engineering, Tottori University 
そこで, 本稿では, 結合価文法による動詞と名詞の訳語選択の有効性を定量的に検証し, 結 合価文法に基づく方式上の限界を検討することを目的とする ${ }^{1}$. 結合価文法では格を介した名詞 と動詞の意味的関係を用いるため, 訳語選択実験に用いる例文は統語的には比較的単純である が意味的には多義のあるほうが望ましい。そこで，評価に用いる例文は，「計算機用日本語基本 動詞・名詞辞書 IPAL」(情報処理振興事業協会技術センター 1996)（以下「IPAL 辞書」と呼 ぶ）に登録されている基本動詞掞よび基本名詞についての例文とする。ここで，例文に掞ける 多義性の度合を読みとるために，よく使われる語義に対する訳語（以下「デフォルト訳語」と 呼ぶ）による訳語選択の精度をあらかじめ調查する，次に，結合価文法をべースにした日英機 械翻訳システム「ALT-J/E」により英訳文（以下「ALT 訳」と呼ぶ）を生成し, 結合価文法に よる訳語選択の精度を調査する。ささらに, ALT 訳での訳語選択誤りの原因を調査し, 結合価文 法の適用範囲で対処可能であるかを考察し, 方式上の限界を議論する。

\section{2 結合価文法による訳語選択}

結合価文法による翻訳では，意味属性による制約の付与された文型パターン対を用いてい る. 意味属性抢よび文型パターン対は, 日本語語彙大系 (池原, 宮崎, 白井, 横尾, 中岩, 小倉, 大山，林 1997) に記載されている.

\section{1 一般名詞意味属性体系}

日本語語彙大系における意味属性体系には，一般名詞意味属性体系，固有名詞意味属性体系， および，用言意味属性体系の 3 種類がある。本節では，パターン選択に直接関わる一般名詞意 味属性体系について概説する。なお，以降では，一般名詞意味属性を単に「意味属性」と呼ぶ.

一般名詞の意味的用法は 2,715 に分類される。この各分類名を一般名詞意味属性という。一 般名詞意味属性体系は，12 段の木構造となっており各ノードに 1 つの意味属性が存在する．た とえば，最上位の意味属性は「名詞」，第 2 段目は意味属性「具体」および意味属性「抽象」で あり,「具体」のすぐ下位には「主体」「場所」および「具体物」という意味属性がある.

一般名詞の単語は，一般に複数の一般名詞意味属性を持つ。たとえば，一般名詞「ビル」は 「施設」拄よび「家屋（全体）」という 2 つの意味属性を持つ。ここで，意味属性「施設」は，意 味属性体系において中段に存在する。すなわち，すぐ上位に意味属性「場所」があり，すぐ下位 の意味属性には「公共施設」「「仕事場」,「住居施設」など 7 つがある。この例で示されるように， 中段の意味属性を用いることで適切な抽象度の意味的用法を単語に割り当てることができる.

1 方式限界とは, その方式で使用する知識デー夕や周辺解析技術が完備されたという条件を仮定した上での上限となる正 解率の推定值である. 知識データや周辺技術の精度向上の困難さから方式の精度向上の困難さが伺える. また, 方式限 界の値は, ベースラインにより最低の評価值の基準を設定することと対極しており, 現状の正解率が限界に迫る程度を 示すので，有効性を定量的に調べる上で必要な值と考える。 
表 1 文型パターン対の例

\begin{tabular}{ccc}
\hline 見出し語 & 日本語文型 & 英語文型 \\
\hline 送る & $N 1$ (人) が $N 2$ (休暇)を送る & $N 1$ spend $N 2$ \\
送る & $N 1$ (人) が $N 2$ (生活)を送る & $N 1$ live $N 2$ \\
起こす & $N 1$ (人) が $N 2$ (人)を起こす & $N 1$ wake $N 2$ \\
起こす & $N 1$ (人) が $N 2$ (訴訟) を起こす & $N 1$ file $N 2$ \\
\hline
\end{tabular}

\section{2 文型パターン}

文型パターンは，用言を見出し語として，その用言の用法ごとに，用言に必須の格要素との 意味的共起関係を定義している. 文型パターンの記述要素は, 名詞部分が変数化された格要素, 用言, および, 必須となる様相である. そして, 格要素と用言の結合性を持たせるために, 変数 に代入可能な名詞の意味属性が制約条件として付随する.さらに，日本語から英語への翻訳の ために，日本語の文型パターンに，英語の文型パターンを対応づける．これらをまとめて「パ ターン対」と呼ぶ.

日本語語彙大系における構文体系には，6,000 語の日本語の用言が登録されている．各見出 し語につき 1 つ以上の文型パターン対が登録されており，全体で 14,800 件の日英文型パター ン対が登録されている。

表 1 に 4 つのパターン対を例示する.「送る」と「起こす」が見出し語で,「 $N+$ 数字」は変 数, 括弧内は一般名詞意味属性である. 表 1 の表記では, 括弧内の意味属性は直前の変数への 制約条件として働き, 変数に代入可能な体言の意味属性を表す。なお, 意味属性体系における 中段の意味属性を，制約条件として記入することができる，その場合，その意味属性よりも下 位の意味属性を持つ名詞が代入可能であることを意味する.

\section{3 結合価文法による訳語選択}

結合価文法を日本文に適用して訳語を選択する基本的な手順を次に示す。

(step.1) 日本文を形態素解析

(step.2) 構文体系から入力文の用言を見出し語とするパターン対を全て検索（場合によっ ては，受身文などの構文を標準形に変形)

(step.3) パターン対ごとに入力文の格要素とパターンに付随する制約を比較

(step.4) 制約条件を最も良く満たすパターン対を選択

(step.5) パターン対の英語文型パターンより動詞の訳語を決定

(step.6) 名詞の表記および (step.4) で限定した意味属性より，単語の訳語辞書を検索し， 名詞の訳語を決定 
形態素解析により，動詞や名詞の異体字は標準表記に変換される．用言に対応するパターンが 登録されていない場合は, 単語の訳語辞書により固定的な英語動詞を訳出する. また, 訳語辞 書にも存在しない場合は, 日本語のまま出力する.

\section{3 評価実験}

\section{1 実験方法}

結合価文法による動詞および名詞の訳語選択の性能を調査するために，評価実験を行なう．

\section{実験システム}

結合価文法を人手で適用して実験することは困難なため, ALT-J/E を用いる，ALT-J/E は， 基本的には，第 2 章で述べた方法で訳語選択を行なっている. ALT-J/E は結合価文法の能力を 最大限に発揮できるようなシステムになっているので, 本評価実験で用いることに適している.

なお, ATL-J/E の翻訳過程において, 形態素解析, 構文・係り受け解析 (パターン候補の 収集と選択を含む), および, 英文の構文生成, に関する情報が得られる。これらの情報は, 後 述する訳語選択の誤り原因の調査で利用する.

\section{評価用例文}

評価実験には，IPAL 辞書に登録されている基本動詞および基本名詞を含む文を用いる。こ の辞書には，日本語で頻繁に用いられる基本動詞（861 語），および，基本名詞（1,081 語）が， それぞれの用法ごとにまとめられている。

日常的に用いられる基本的な単語は多義を持つものが多い. 特に IPAL 辞書の基本動詞は和 語系の動詞であり多義がある。一般に訳し分けが困難であるため, 結合価文法による意味解析 能力が試される。また，この辞書に含まれる例文は，単文が多く含まれており，結合価文法を 適用する前の段階で，解析に失敗することが少ないと期待できる。よって，方式上の限界を見 つけることにも適しているといえる。

なお，IPAL 辞書に記載されている例文は日本語文のみである．このため，基本動詞の例文 については，翻訳家に依頼して対訳 (英語文) を作成した。本稿ではこの対訳を「正解訳」と する。一方，基本名詞については，正解訳を作成する都合により，上述の対訳，および，機能 試験文集 (池原, 白井，小倉 1994) から基本名詞を含む例文をランダムで抽出し，正解訳として 収集する。評価実験は，動詞に関しては 5,242 文対，名詞に関しては 1,062 文対について行う。 


\section{2 評価方法}

評価は，ALT-J/E で機械翻訳した英訳文（ALT 訳）のうちの注目単語について，正解訳の 英単語と比較して行なう。注目単語は，1文に 1 つだけ用意する。なお, 評価は, 動詞と名詞の いずれについても同じ基準で行なう.

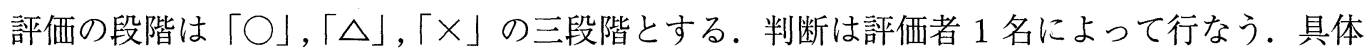
例を以下に示す。

評価 $\bigcirc ：$ 注目する単語が, ALT 訳と正解訳で一致する場合

例文 1 : 二つの川がこの地点で合う。

正解訳 1 : The two rivers join at this point.

ALT 訳 1: Two rivers join in this point.

例文 2 : 彼は皆の 注目を集めた。

正解訳 2: He attracted the attention of everyone.

ALT 訳 2: He attracted the attention of everybody.

評価 $\triangle$ ：注目する単語が, ALT 訳と正解訳で異なるが, 意味的に正しい場合

例文 3 ：彼は準備を急いだ。

正解訳 3 : He prepares quickly.

ALT 訳 3 : He hurried preparation.

例文 4 ：私たちは今日その問題を話し合った。

正解訳 4 : We discussed the matter today.

ALT 訳 4: We talked about that problem today.

評価X：注目する単語が，ALT 訳では間違っている場合

例文 5 ：彼らは海底に沈んでいた船を陸に揚げた。

正解訳 5: They salvaged the sunken vessel on the bottom of the sea.

ALT 訳 5: They deep-fried in land the ships that had sunk in the bottom of the sea.

\section{3 実験結果}

基本動詞および基本名詞についての各実験結果を，表 2 ，および，表 3 に示す。ここで，デ フォルト訳語とは，各見出し語の訳語の中で最も良く使われる語のことで，プロシード和英辞 典 (長谷川, アラン, 橋本 1988) で先頭に表記されている英単語をデフォルト訳語とする ${ }^{2}$.

2 予備実験として, ALT-J/E，商用ソフト「翻訳魂」（オムロンソフトゥエア（株）1999），㧍よび, ニューアンカー英 和・和英辞典 (柴田，山岸 1997) によるデフォルト訳語のそれぞれを用いて, 評価用例文 1,111 文を対象に, 動詞の訳 語選択を行った．各正解率は， $89 \%, 67 \% ， 58 \%$ ，であった。 
表 2 動詞の訳語選択についての正解率

\begin{tabular}{ccc}
\hline 評価 & ALT-J/E & デフォルト訳語 \\
\hline$\bigcirc$ & 2,571 文 $(49 \%)$ & 1,141 文 $(22 \%)$ \\
$\triangle$ & 2,073 文 $(40 \%)$ & 1,740 文 $(33 \%)$ \\
$\times$ & 598 文 $(11 \%)$ & 2,361 文 $(45 \%)$ \\
\hline
\end{tabular}

表 3 名詞の訳語選択についての正解率

\begin{tabular}{ccc}
\hline 評価 & ALT-J $/ \mathrm{E}$ & デフォルト訳語 \\
\hline$\bigcirc$ & 658 文 $(62 \%)$ & 615 文 $(58 \%)$ \\
$\triangle$ & 312 文 $(29 \%)$ & 289 文 $(27 \%)$ \\
$\times$ & 92 文 $(9 \%)$ & 158 文 $(15 \%)$ \\
\hline & & (合計 1,062 文)
\end{tabular}

\section{4 考察}

\section{1 動詞の訳語選択に関する考察}

\section{動詞の訳語選択への有効性}

表 2 よりデフォルト訳語の正解率（評価○と $\triangle$ の合計值）が $55 \%$ であったことから, 動詞 の訳語選択の困難さがわかる。ALT 訳の正解率が $89 \%$ であったことから，結合価文法による 動詞の訳語選択の効果が高いことがわかる．4.1項では，有効性についての考察を深める.

動詞の訳語選択の正否を左右する大きな要因は，動詞に割り当てられた語義の数，すなわち， 結合価パターンの数である．本実験の対象となった動詞がどれだけの多義を持つものであるか， 訳語選択に成功した事例は，多義数に関してどのような分布をしているのか，について考察す る必要がある。

そこで, 登録されているパターンの数で動詞を分類し，訳語選択の評価の分布を調査した。 結果を表 4 に示す.

まず，評価文の性質を読み取る，表 4 より登録パターン数ごとの評価文数を数えると，登録 数が 0 個の動詞は 29 文で, 全体の 5,242 文のうち $0.5 \%$ であった. 登録数が 1 から 5 個の動 詞は 2,289 文 $(44 \%)$, 登録数が 6 から 10 個の動詞は 1,490 文 $(28 \%)$, 登録数が 11 個以上の 動詞は 1,434 文 $(27 \%)$ であった。

次に, 正解の仕方について読み取る. 登録パターン数が 0 個の動詞については, 誤り率（評 価×）が $66 \%$ であった. 登録数が 1 個以上の動詞に比べ, 著しく誤り率が高い. 一方, 登録 されているパターン数が多い程, パターンの選択肢が多く, 同時に動詞訳語の選択肢も多くな 
表 4 パターンの数別の正解率

\begin{tabular}{|c|c|c|c|c|}
\hline 評価基準 & 0 個 & 1 $\sim 5$ 個 & $6 \sim 10$ 個 & 11 個以上 \\
\hline 0 & 1 文 $(3 \%)$ & 1,100 文 $(48 \%)$ & 771 文 $(52 \%)$ & 699 文 $(49 \%)$ \\
\hline$\triangle$ & 9 文 $(31 \%)$ & 963 文 $(42 \%)$ & 555 文 $(37 \%)$ & 546 文 $(38 \%)$ \\
\hline$x$ & 19 文 $(66 \%)$ & 226 文 $(10 \%)$ & 164 文 $(11 \%)$ & 189 文 $(13 \%)$ \\
\hline
\end{tabular}

表 5 正しく動詞訳語が出せなかった原因

\begin{tabular}{clr}
\hline & 動詞訳語の誤選択の原因 & \multicolumn{1}{c}{ 割合 } \\
\hline 1 & パターンの照に合に失敗した & 45 文 $(37 \%)$ \\
2 & 正解となるパタージ登録されていない & 26 文 $(21 \%)$ \\
3 & 係り受け解析に失敗した & 21 文 $(17 \%)$ \\
4 & 慣用表現が用いられてる & 13 文 $(11 \%)$ \\
5 & 形態素解析に失敗した & 11 文 $(9 \%)$ \\
6 & 例文が二通りの意味にとれる & 6 文 $(5 \%)$ \\
\hline
\end{tabular}

る.そのため, パターン選択の誤りによる精度の低下が懸念される。しかし，表 4 における登録 数が 1 個以上の動詞での誤り率は，10\% 13\% と，安定していることがわかる.

以上より，結合価文法は，動詞の訳語選択における効果が顕著であり，かつ，語義数が多い ものでも安定していることが定量的に明かになった。

\section{訳語誤選択の原因と解決方法}

$\mathrm{ALT}-\mathrm{J} / \mathrm{E}$ が正しく訳語を選択できなかった原因を明らかにするために，評価がメとなった 例文 589 文中 122 文について調査した。結果を表 5 に示す，以下にそれぞれの原因に対する解 決方法を考察する.

原因 1 : パターンの照合に失敗した 一つの動詞に対して複数のパターンが登録されていると， 日本語文に対するパターンの選択が問題になる。具体例を示す.

例文 6 ：彼は海外で夏休みを送った。

正解訳 6 : He spent his summer vacation abord.

ALT 訳 6: He saw a summer vacation off at a foreign country.

動詞「送る」の場合，12 種類のパターンが日本語語彙大系に登録されている。この例文に 対しては「N1(人) が $N 2$ (時間，休暇)を送る/N1 spend $N 2 」$ のパターンを適用すれば，正 しい訳語が導き出される。しかし，実際には,「N1(人) が $N 2$ (主体) $N 3$ (場所，場，建造物) 
で送る $/ N 1$ see $N 2$ off at/in $N 3 」$ が適用され，誤った訳語が選択されている。これは，文と パターンを照合するアルゴリズムの問題である. 現在, 改善方法が研究されている (吉田, 池 原，村上 2002$)^{3}$.

原因 $2:$ 正解パターンが登録されていない 正解の訳語を導くパターンが登録されていない場 合，パターンを用いた訳語選択ができない. 具体例を示す.

例文 7 ：学生が教授に教授の都合を電話で伺った。

正解訳 7: The student phoned the professor and asked him when he would be free.

ALT 訳 7：A student listened the professor's circumstances with a telephone to a professor.

動詞「伺う」のパターンが「N1(人) が $N 2$ (人)の·N3(陳述) を伺う／ $N 1$ listen to $N 2 」$ と しか登録されていないため,「伺う」を用言として持つ文に対してはこのパターンしか適用され ず，他の訳語を選択できない。この対策としては，不足しているパターンを補うことがあげら れる。具体的にこの例文の場合, 「N1(人) が $N 2$ (人) に $N 3$ (状態)を伺う／N1 ask $N 2$ 's $N 3 」$ をパターン辞書に追加することにより目的の訳語「ask」が選択できると推測される.

原因 3：係り受け解析に失敗した, 原因 5：形態素解析に失敗した これらは，結合価文法を 用いる以前の処理での問題である.これらの処理が正しく行われないと, 結合価文法を使うこ とができない.

原因 4: 例文に慣用表現が用いられている 慣用表現が用いられている具体例を示す.

例文 8 ：彼は話の腰を折った.

正解訳 8: He interrupted a person's speech.

ALT 訳 8: He broke the waist of talk.

慣用表現は言い回しが決まっているので，パターンの記述に意味属性を用いずに，表現に含 まれる名詞の字面を記述することで解決でき，既に，日本語語彙大系には，3,300 件の慣用表現 がこうして登録されている，今後，さらなる追加により解決できる.

具体的には例文 8 に対しては,「N1(人) が話の腰を折る／N1 interrupt a speech」という パターンを登録することで正しい訳語が選択できる.

原因 6 ：例文が二通りの意味にとれる 例文が二通りの意味にとれる具体例を示す.

例文 9 ：彼が転んだ彼女を起こした。

正解訳 9: He picked her up after she fell down.

ALT 訳 9: He woke up the woman who fell down.

3 現在, NTT が改良をすすめている ALT-J/E（ver.01.20）は例文 6 を正しく訳出する. 
例文 9 は，正解訳のとおり「彼が彼女の体を起こした」という意味である。しかし，パター ンの該当部分「彼女を起こした」だけに注目すると，正解訳の意味とは別に，「目覚めさせた」 という意味にも解釈できる。よって「N1が $N 2$ を起こす」は, 文によって「pick〜up」と 「wake up 〜」の二つの訳語を使い分ける必要がある，ところがその使い分けには，この文の因 果関係に注目する必要がある。一般に因果を表す文は, 原因と結果をそれぞれ節で表すため複 文となる。そのため単文レベルのパターンでは対処できない.これは, 現在の結合価文法によ る訳し分けの限界だと言える。今後, 複文・重文も考慮に入れたパターンが必要になる.

\section{動詞のまとめ}

動詞の訳語選択において結合価文法は動詞の多義数が多くなっても安定して訳し分けが可能 であることがわかった。一方，誤り原因の多くは，結合価文法を用いる以前の段階（原因 3,5）, パターン登録の有無に依るもの（原因 2,4），および，パターン照合の方法（原因 1），であり， 既存技術の改良, ならびに, 結合価文法のパターン追加と照合アルゴリズムの改良により対処 可能である。しかし, 原因 6 については現在の結合価文法の枠組みを越えるため改善が困難で ある。

したがって, IPAL 辞書の動詞について, 正解率の現状は $89 \%$ あ゙り, 方式上の正解率の限 界は $99 \%$ ある。

\section{2 名詞の訳語選択に関する考察}

\section{名詞の訳語選択への有効性}

表 3 より ALT-J/E とデフォルト訳語との正解率の差は $6 \%$ である.したがって，名詞の 訳語選択において結合価文法は，動詞の場合ほど，顕著な効果は認められなかった。これは， IPAL 辞書の名詞の約 5 割が多義を持たないため, デフォルト訳語の正解率が元々高いためで ある。

\section{先行研究との比較}

デフォルト訳語の正解率が高いことをうけ，評価用例文の内訳を調べる．

名詞の訳語選択の正否を左右する大きな要因は, 名詞に付与した一般名詞意味属性による訳 語選択の分解能である。つまり，見出し語と意味属性の組で訳語を選択するため，その組と訳 語の対応関係が一対一ならば正解訳が期待でき, 逆に, 一対多ならば訳語選択が困難になる.

この観点から名詞の訳語選択については, 名詞の意味属性が決まることにより訳語多義 4 の あるIPAL 辞書の名詞がどれだけ訳し分けられるかを調査した研究がある(桐澤, 池原, 村上

4 本稿では, 1 つの日本語名詞に複数の英訳語が存在することをいう. 
表 6 訳語多義に基づく名詞分類ごとの訳語選択精度

\begin{tabular}{crrr}
\hline 分類 & \multicolumn{1}{c}{$\bigcirc$} & \multicolumn{1}{c}{$\triangle$} & \multicolumn{1}{c}{$\times$} \\
\hline 一意に訳し分け可能 & 166 文 $(56 \%)$ & 93 文 $(32 \%)$ & 36 文 $(12 \%)$ \\
場合により訳し分け可能 & 16 文 $(48 \%)$ & 14 文 $(42 \%)$ & 3 文 $(9 \%)$ \\
絞り込み可能 & 54 文 $(44 \%)$ & 49 文 $(40 \%)$ & 19 文 $(16 \%)$ \\
訳し分け不可能 & 31 文 $(52 \%)$ & 19 文 $(32 \%)$ & 10 文 $(17 \%)$ \\
\hline 合計 & 267 文 $(52 \%)$ & 175 文 $(34 \%)$ & 68 文 $(13 \%)$ \\
\hline (参考：訳語多義なし & 391 文 $(71 \%)$ & 137 文 $(25 \%)$ & 24 文 $(4 \%))$
\end{tabular}

2000).この研究では, 訳語多義を次の 4 つに分類している.

一意に訳し分け可能：意味属性ごとに 1 つの訳語が対応

場合により訳し分け可能：ある意味属性を除き，意味属性ごとに 1 つの訳語が対応

絞り込み可能：意味属性ごとに複数の訳語が対応

訳し分け不可能：意味属性はただ 1 つであり，複数の訳語が対応

この分類から,「一意に訳し分け可能」の場合は最も正しい訳語選択が可能であり，「場合により 訳し分け可能」および「絞り込み可能」の場合はそれほど明確な選択精度が得られず，そして， 「訳し分け不可能」の場合は訳語選択の誤りが最も多いと予想できる.

そこで, 本稿の結果をこの分類に当てはめ, 各分類ごとに訳語選択の評価の分布を調査した. 結果を表 6 に示す.

まず，評価文の性質を読み取る，表 6 より分類ごとの評価文数を数えると,「一意に訳し分け 可能」となる名詞は 295 文で, 全体の 1,062 文のうち $28 \%$ であった. 残りの 3 つの分類項目 に対する名詞は，それぞれ，33 文 $(3 \%) ， 122$ 文 $(11 \%), 60$ 文 $(6 \%)$ であった。また,「訳語多 義なし」に対する名詞は 552 文 $(52 \%)$ であった。

次に，正解の仕方について読み取る。「合計」について見ると，訳語多義のある名詞を含む 評価用例文は 510 文あり，52\% が完全一致による正解 $(\bigcirc), 34 \%$ が意味的一致による正解 $(\triangle)$ ，そして，13\% が誤り $(\times)$ であった。これらの值と比較しながら各分類の分布をみる と，上述の (桐澤他 2000) からの予想どおり「一意に訳し分け可能」の場合は○となる割合が高 く,「場合により訳し分け可能」および「絞り込み可能」の場合は $\Delta$ なる割合が高く，そして， 「絞り込み可能」および「訳し分け不可能」の場合は×となる割合が高かった。しかし，「訳し分 け不可能」の分類において○となる割合は，他の分類における○の割合と大きな差が認められ なかった.

以上より，結合価文法は名詞の訳語選択における効果が顕著でないことがわかった.

なお，名詞の訳語選択の評価実験では評価用の例文が 1,062 文であり，動詞の場合と比べて 少ない. しかし，上述の比較により，先行研究と一致する傾向が観測されるほどの例文数を対 象とできているので，ある程度妥当な例文数といえる。 
表 7 正しく名詞訳語が出せなかった原因

\begin{tabular}{llr}
\hline & 名詞訳語の誤選択の原因 & \multicolumn{1}{c}{ 割合 } \\
\hline 1 & 正解となるパターンが登録されていない & 36 文 $(39 \%)$ \\
2 & 慣用表現が用いられている & 22 文 $(24 \%)$ \\
3 & パターンの格要素の意味が十分に限定できていない & 16 文 $(17 \%)$ \\
4 & 評価対象の名詞がバターンの必須格でない & 7 文 $(8 \%)$ \\
5 & 形態素解析に失敗した & 5 文 $(5 \%)$ \\
6 & パターンの照に合に失敗した & 4 文 $(4 \%)$ \\
7 & 評価対象の名詞が辞書に登録されていない & 2 文 $(2 \%)$ \\
\hline
\end{tabular}

\section{訳語誤選択の原因と解決方法}

動詞の訳語誤選択と同様に，ALT-J/E が正しく訳語を選択できなかった原因を，評価がメ となった例文 92 文について調査した. 結果を表 7 に示す. 以下に解決方法を考察する.

原因 1,2,5,6 および 7 について 原因「1. 正解となるパターンが登録されていない」,「2. 慣 用表現が用いられている」,「5. 形態素解析に失敗した」,「6. パターンの照合に失敗した」，お よび,「7. 評価対象の名詞が辞書に登録されていない」については, 前節の動詞の考察と同様で ある。

原因 $3:$ パターンの格要素の意味が十分に限定できていない パターンに付随している格要素を 制約する意味属性に注目すると,「* (任意の意味属性)」や「主体」などのように，格要素に適 合する意味属性を制限しないもの，あるいは，意味属性体系においてかなり上位の階層にありあ まり限定力のないものが見受けられる。意味属性制約の抽象度が高い場合，文中で使われてい る名詞の意味属性を一意に絞りこめないため，訳語が選択できない場合がある．具体例を示す．

例文 10：彼は相手に意向を質した。

正解訳 10: He asked the other party of their intention.

ALT 訳 10: He asked his partner about a mind.

例文 10 には「N1(主体) が $N 2$ (主体)に $N 3$ (抽象) を質す」というパターンが対応する. 例 文 10 の訳し分け対象の名詞「意向」には「意図」および「思想」という 2 つの意味属性が定義 されている。しかし，この 2 つの意味属性は共に意味属性「抽象」の下位に位置する意味属性 である.よって，このパターンは「意向」の意味属性を一意に決定できない.

この原因は，パターンが用言の訳し分けを主目的に作られたためであると考えられる。つま り，パターンを作成する際，同一の見出し語，同一の英語用言，かつ，同一の用言意味属性と なるパターンを統合する段階において，同一見出し語の範囲で，他の英語用言を持つパターン と区別できる程度まで格要素の意味属性を抽象化したためである。よって，その意味属性の範 
囲内での格要素の名詞の訳し分けは保障されていない。

解決方法として,「N1(主体) が $N 2$ (主体) に $N 3$ (意図, 思想) 質す」という意味属性の制 約を強めたパターンを追加することが挙げられる.ただし, 全ての名詞・用言について網羅し ようとするとパターン数が爆発的に多くなることが問題となる.

原因 4：評価対象の名詞がパターンの必須格でない 評価対象の名詞のある格要素が，パター ンで制約されていない場合には，結合価文法の効果が得られない。具体例を示す.

例文 11 ：逃亡した男は地方で生き延びている。

正解訳 11 : The man who escaped is surviving in the countryside.

ALT 訳 11: The man who escaped has survived in a district.

名詞「地方」には，3つの意味属性「地域 (範囲)」,「村落」および「辺り」が定義されてい る. ALT 訳の「district」は「地域（範囲）」の訳語である.「田舎」の意味合いを含む訳出のた めには，意味属性を「村落」に絞る必要がある，ところが，ALT 訳では，パターン「N1(主体， 動物) が 生き延びる」が適用されており,「で格」はパターンの格要素に含まれていない.

このようなパターン外の格要素については，個別の規則が働く。たとえば,「N1(地域)で」 と「N1(道具) で」により「in」と「with」が使い分けられる。ここで，例文 11 に対して，前 者の規則が適用され「辺り」という意味属性は除外される。しかし，「地域 (範囲)」と「村落」 は，兄弟関係にあり，ともにすぐ 1 つ上位に「地域」という共通の意味属性があるため，この 事例に対処できない。これに対しては，より細かい意味属性を用いた規則を大量に設ける必要 がある。

\section{名詞のまとめ}

結合価文法による名詞の訳語選択の能力は, さほどの効果が無かった. それは主に, パター ンに付随する格要素への意味的制約が，用言の意味的用法を同定するために定義されている， すなわち，名詞の訳語選択に必要な粒度で意味属性の制約が定義されていないためである．名 詞の訳語選択についてはパターンが適用されても十分な効果が得られないため, 原因 3 は方式 上解決できない．また，原因 4 は小規模なパターンの修正では改善が困難である.

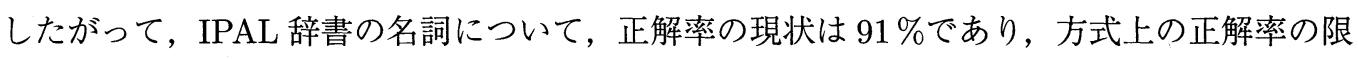
界は $97 \%$ あるる。

\section{5 まとめ}

本稿では, IPAL 辞書に登録されている基本動詞および基本名詞に関する文を評価用例文と して, 動詞および名詞の訳語選択を結合価文法に基づく手法で行い，その精度を調査した。そ の結果, 動詞については $89 \%$, 名詞については $91 \%$ の正解率となった。これはデフォルトの 
訳語と比べ $34 \%, 6 \%$ 高い精度である。このことより, 動詞についての効果は結合価文法に基 づく方法において顕著であるのに対して，名詞についてはそれほど顕著ではないことが明かに なった。これは，結合価文法が本来用言の訳語選択を目的として開発されたことが主な原因で ある。次に，訳語選択に失敗した原因を分析し，その対策を検討した。その結果，パターンの 拡充および既存技術の改良などにより正解率を向上させる余地があった.よって，これらの余 地を全て解決した際の訳し分けの正解率の限界, すなわち, 結合価文法による訳語選択の方式

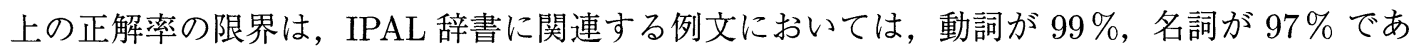
ると推測した.

今後の課題として，より複雑な言語構造のある場合の結合価文法の問題点を調べるために， 新聞記事などの実務的な文章を対象に評価実験を行うこと,より一般的な訳語選択の手法との 相対的な評価を行うために，商用の翻訳ソフトなどによる他の手法との比較すること，などが あげられる。

\section{謝辞}

本稿で用いた日英機械翻訳システム「ALT-J/E」および言語関係の資源は，NTT との共同研 究の下で使用させて頂きました。ここにお礼申し上げます，また，貴重なコメントを下さった 査読者の方に感謝の意を表します。

\section{参考文献}

長谷川潔, アランターニー, 橋本光郎 (1988). プロシード和英辞典. 福武書店.

池原悟, 宮崎正弘, 横尾昭男 (1993). “日英機械翻訳のための意味解析用の知識とその分解能.”

情報処理学会論文誌, 34 (8), pp. 1692-1704.

池原悟, 宮崎正弘, 白井諭, 横尾昭男, 中岩浩巳, 小倉健太郎, 大山芳史, 林良彦 (1997). 日 本語語彙大系 5 構文体系. 岩波書店.

池原悟，白井諭，小倉健太郎 (1994)。“言語表現体系の違いに着目した日英機械翻訳試験項目の

構成.” 人工知能学会論文誌, $9(5)$, pp. 569-579.

情報処理振興事業協会技術センター (1996). 計算機用日本語名詞辞書 IPAL 解説編. 情報処理振 興事業協会技術センター. http://www.ipa.go.jp/STC/NIHONGO/IPAL/ipal.html.

角田達彦，田中英彦 (1996). “英語名詞の多義性解消における文脈としての場面情報の評価.”自 然言語処理, 3 (1), pp. 3-27.

柏野（桑畑）和佳子, 本多啓 (1998). “IPAL 名詞辞書における多義構造の記述.” 情報処理学会 論文誌, 39 (9), pp. 2603-2612.

桐澤洋, 池原悟, 村上仁一 (2000). “日英機械翻訳における名詞の訳語選択.”言語処理学会第 6 回年次大会発表論文集, pp. 55-58. 
北村博，荻野紫穂 (1990). “日英翻訳における連体修飾句の訳し分け.” 情処研報, 90-NL-75, pp. 1-8.

黒橋禎夫, 白井清昭, 隅田英一郎, 武田浩一, 鳥澤健太郎, 橋田浩一（編） (2003). 自然言語 処理 特集号「SENSEVAL-2 日本語タスク」, 10 (3). 言語処理学会.

桑畑和佳子, 橋本三奈子, 青山文啓 (1998). “IPAL 名詞辞書による多義性解消のためのコロ ケーションの分析.”情報処理学会論文誌, 39 (6), pp. 1925-1934.

三浦つとむ (1967). 認識と言語の理論, 1 3. 勁草書房.

水谷静夫, 石棉敏雄, 荻野孝野, 賀来直子, 草薙裕 (1983). 文法と意味 I. 朝倉書店.

野美山浩 (1991). “目的言語の知識を用いた訳語選択とその学習性.” 情処研報, 91-NL-86, pp. 1-8.

柴田徹士, 山岸勝榮 (1997). ニューアンカー英和・和英辞典. 学習研究社.

鈴木克志，太細孝 (1991). “日英機械翻訳における共起表現の扱い.”情処研報, 91-NL-82, pp. 1-8.

吉田真司，池原悟，村上仁一 (2002). “入力文に対する結合価パターン対の選択方法について.” 言語処理学会第 8 回年次大会発表論文集, pp. 229-302.

\section{略歴}

金出地 真人： 2001 年鳥取大学工学部知能情報工学科卒業. 2003 年同大学大学 院工学研究科博士前期課程修了. 現在, (株) INAX に勤務.

徳久 雅人: 1995 年九州工業大学大学院情報工学研究科博士前期課程修了. 同 年同大学情報工学部助手．統合的知能エージェントの開発に従事．現在，鳥 取大学工学部助手. 自然言語処理の研究に従事. 情報処理学会, 電子情報通 信学会, 人工知能学会, 言語処理学会各会員.

村上 仁一: 1984 年筑波大学第 3 学群基礎工学類卒業. 1986 年筑波大学修士課 程理工学研究科理工学専攻修了. 同年 NTT に入社. NTT 情報通信処理研 究所に勤務. 1991 年国際通信基礎研究所 (ATR) 自動翻訳電話研究所に出向. 現在, 鳥取大学工学部助教授. 主に音声認識のための言語処理の研究に従事. 電子情報通信学会, 日本音響学会, 言語処理学会各会員.

池原 悟: 1967 年大阪大学基礎工学部電気工学科卒業. 1969 年同大学大学院修 士課程修了. 同年日本電信電話公社に入社. 数式処理, トラフィック理論, 自 然言語処理の研究に従事. 1996 年スタンフォード大学客員教授. 現在, 鳥取 大学工学部教授. 工学博士. 1982 年情報処理学会論文賞, 1993 年同研究賞, 1995 年日本科学技術情報センター賞 (学術賞), 同年人工知能学会論文賞, 2002 年電気通信普及財団賞（テレコム・システム技術賞）受賞，電子情報通 信学会, 人工知能学会, 言語処理学会, 機械翻訳協会各会員. 
自然言語処理 Vol. 11 No. 3

(2003 年 8 月 11 日受付)

(2004年 1 月 10 日 再受付)

(2004 年 3 月 14 日再々受付)

(2004 年 4 月 12 日採録) 